\title{
Perbandingan Frekuensi dan Durasi Perilaku Seksual Berdasarkan Umur pada Pejantan Ayam Burgo
}

\section{Comparison of Frequency and Duration of Male Burgo Sexual Behaviors Based on Age}

\author{
H. D. Putranto ${ }^{1}$, J. Setianto ${ }^{1}$, Y. Yumiati ${ }^{2}$, dan E. Nurandriyanto ${ }^{1}$ \\ ${ }^{1)}$ Jurusan Peternakan, Fakultas Pertanian Universitas Bengkulu, \\ Jalan W.R.Supratman, Kandang Limun, Bengkulu 38371 \\ ${ }^{2)}$ Program Studi Agribisnis, Fakultas Pertanian Universitas Dehasen Bengkulu, \\ Jalan Raya Meranti, Sawah Lebar, Bengkulu 38227 \\ Corresponding e-mail : heri_dp@unib.ac.id
}

\begin{abstract}
The purpose of the study was to compare serial sexual behaviors (courtship, mounting, mating, and dismounting) based on age in male Burgo chickens. The research was conducted during April to June 2018 at Integrated Livestock Zone, Department of Animal Science, Faculty of Agriculture UNIB. The parameters observed were the frequency and duration of series of Burgo chicken male sexual behaviors consisting of courtship, mounting, mating, and dismounting in males number 1 and 2 (younger adults) and males number 3 and 4 (older adults). Data were tabulated and analyzed descriptively. We found that highest frequency of courtship behavior was carried out by male number 1 (average of 14.1 times) with duration of 27.98 seconds. The highest frequency of mounting, mating and dismounting were carried out by male number 3 with an average of 4.7 times, 4.9 times and 4.7 times and an average duration of 7.73 seconds, 6.79 seconds and 5.75 seconds, respectively. Based on the results of the study, it was found that older adult Burgo were higher in frequency of sexual behaviors, except in courtship where younger Burgo males were more active.
\end{abstract}

Keywords: Age, burgo chicken, duration, frequency, male, sexual behavior.

\begin{abstract}
ABSTRAK
Tujuan dari penelitian adalah untuk membandingkan serial perilaku seksual (courtship, mounting, mating, dan dismounting) berdasarkan umur pada ayam Burgo jantan. Penelitian telah dilaksanakan pada bulan April hingga Juni 2018 bertempat di Zona Peternakan Terpadu (Integrated Livestock Zone) Jurusan Peternakan FP UNIB. Parameter yang diamati adalah frekuensi dan durasi dari serial perilaku seksual pejantan ayam Burgo yang dipelihara secara intensif yang terdiri dari courtship, mounting, mating, dan dismounting pada pejantan nomor 1 dan 2 (dewasa berumur lebih muda) serta pejantan nomor 3 dan 4 (dewasa yang berumur lebih tua). Kemudian data hasil pengamatan ini ditabulasi dan dianalisis secara deskriptif. Peneliti mendapati bahwa frekuensi tertinggi perilaku courtship dilakukan oleh pejantan nomor 1 (rerata 14,1 kali) dengan rerata durasi 27,98 detik. Pada perilaku mounting, mating dan dismounting frekuensi tertinggi dilakukan oleh pejantan nomor 3 dengan rerata masing-masing 4,7 kali; 4,9 kali dan 4,7 kali dengan rerata durasi masing-masing 7,73 detik; 6,79 detik dan 5,75 detik. Berdasarkan hasil penelitian diketahui bahwa pejantan ayam Burgo dewasa yang berumur lebih tua lebih tinggi frekuensi perilaku seksualnya, kecuali pada tingkah laku seksual courtship dimana pejantan ayam Burgo dewasa yang berumur lebih muda lebih aktif.
\end{abstract}

Kata Kunci: Ayam Burgo, durasi, frekuensi, pejantan, perilaku seksual, umur.

\section{PENDAHULUAN}

Nusantara yang berada di sepanjang garis khatulistiwa menyimpan banyak sekali kekayaaan fauna berupa spesies hewan yang belum banyak digali informasinya oleh para peneliti. Spesies hewan yang berpotensi untuk dikembangkan sebagai ternak unggas lokal di Pulau Sumatera adalah ayam Burgo
(Putranto et al., 2018; Setianto et al., 2019). Ayam Burgo yang selanjutnya disebut dengan Burgo atau Berugo merupakan ayam atau unggas eksotik dan endemik di Provinsi Bengkulu (Putranto et al., 2018, 2017, 2016, 2012a, b; Putranto, 2011; Setianto et al., 2019). Bahkan dalam rangka menyongsong 
kegiatan Wonderful Bengkulu 2020, Pemerintah Provinsi Bengkulu telah menetapkan ayam Burgo atau Berugo atau Brugo sebagai salah satu ikon kegiatan berdampingan dengan ikon bunga Raflesia (Anonim, 2019).

Sebagai salah satu plasma nutfah ayam eksotis endemik Bengkulu, spesies ini telah dipelajari dengan seksama oleh peneliti dari Universitas Bengkulu. Informasi biologi yang telah diketahui antara lain DNA mitokondria ayam Burgo (Putranto et al., 2012a), hormon reproduksi betina dan sel telur (Putranto et al., 2012b) serta ukuran morfometriknya (Handika, 2018; Putranto et al., 2018). Sehubungan dengan kegiatan konservasi dan studi populasi maka telah pernah dipelajari tentang populasi ayam Burgo kelamin campuran (Putranto et al., 2010) serta populasinya pada daerah pesisir Bengkulu dengan aplikasi perangkat lunak sederhana (Putranto et al., 2017). Akan tetapi ternyata data tentang perilaku pada ayam Burgo jantan dan betina sampai saat ini masih belum banyak diketahui. Oleh karena itu, peneliti meyakini bahwa dalam rangka pengembangan populasi dan budidaya ayam Burgo sebagai ternak unggas lokal maka informasi tentang perilaku menjadi penting untuk diketahui.

Etologi sebagai salah satu cabang ilmu yang membahas tentang perilaku hewan/ternak telah cukup berkembang dalam kurun waktu 50 tahun terakhir. Pengetahuan tentang perilaku menjadi sangat penting untuk diketahui sebagai salah satu dasar utama dalam manajemen pengelolaan dan budidaya hewan potensial. Menurut Anonim (2017), perilaku adalah suatu bentuk aktivitas ternak yang melibatkan fungsi fisiologis sebagai hasil dari perpaduan antara aktivitas keturunan dengan pengalaman individu dalam menanggapi atau menghadapi suatu objek. Lebih lanjut, dengan perilaku memungkinkan seekor hewan untuk menyesuaikan diri terhadap perubahan keadaan, baik eksternal maupun internal.

Sawitri dan Takandjandji (2010) melalui studinya tentang perilaku pada burung elang di lingkungan ex situ menyebutkan bahwa observasi etiologi dapat disimpulkan sebagai langkah biology assessment yang penting. Melalui pengamatan perilaku kita bisa memantau kesehatan, perkembangbiakan dan kemampuan adaptasi dari satu atau lebih spesies fauna. Berdasarkan hasil studi lainnya (Anonim, 2017; Nurandriyanto, 2018) diketahui bahwa perilaku seksual beberapa unggas jantan ataupun aves jantan saat akan melakukan perkawinan maka jantan akan menari, memanjangkan kepala dan menegakkan jengger dan bulu leher sebagai bentuk aktivitas rayuan dan perangsangan, melakukan penunggangan (mounting). Bulu lehernya akan terangkat dan membuka kloaka dilanjutkan dengan ejakulasi sebagai bentuk aktivitas mating, selanjutnya turun ke arah depan yang diartikan sebagai dismounting. Peneliti lainnya (Setioko, 2001) menulis bahwa terdapat 5 perilaku seksual alami pada itik, yaitu tahap perayuan (courtship), tahap naik diatas punggung dan mengatur posisi (mounting and positioning), perangsangan betina (stimulating), ereksi dan ejakulasi (erection and ejaculation), dan gerakan setelah kawin (post coital display). Selanjutnya Appleby et al. (2004) menyatakan bahwa aktivitas frekuensi kawin pada unggas akan berkurang seiring meningkatnya umur, tetapi dampaknya tidak secara langsung mempengaruhi fertilitas telur,

Studi yang dilakukan tim peneliti ini bertujuan untuk untuk membandingkan serial perilaku seksual (courtship, mounting, mating, dan dismounting) berdasarkan umur pada pejantan ayam Burgo. Sebagai salah satu upaya komprehensif dalam mempelajari ayam Burgo sebagai plasma nutfah endemik dan lokal Bengkulu utamanya tentang reproduksi, maka studi perilaku seksual akan memberikan kontribusi signifikan terhadap informasi biologi dalam program budidaya dan konservasinya. 


\section{MATERI DAN METODE}

\section{Alat dan Bahan}

Alat yang dipergunakan dalam penelitian ini antara lain jam, timer atau stopwatch, alat tulis, kamera untuk dokumentasi berupa gambar dan video, serta alat-alat pendukung lainnya seperti perlengkapan pakan dan minum yang diletakkan di dalam setiap kandang individual jantan. Bahan atau objek penelitian adalah 4 ekor pejantan ayam Burgo yang sudah dewasa kelamin (berumur 6 sampai 12 bulan) yang dipelihara secara intensif pada kandang individual jantan. Pejantan ayam Burgo yang diamati terdiri atas 2 ekor pejantan dewasa berumur muda (6 dan 7 bulan) dan 2 ekor pejantan dewasa berumur lebih tua (12 bulan).

\section{Metode Penelitian}

Observasi perilaku pada penelitian ini menggunakan metode scan sampling yaitu peneliti mencatat semua aktivitas yang terlihat dalam keseluruhan aktivitas harian (Tanari, 2007). Untuk membagi waktu observasi perilaku dipergunakan metode time sampling (Nareswari et al., 2017), yaitu mencatat frekuensi terjadinya perilaku seksual pada selang waktu tiga jam, selama 6 jam setiap hari, mulai pukul 06.00 - 09.00 WIB dan 12.00 - 15.00 WIB, kemudian pada hari berikutnya mulai pukul $09.00-12.00$ WIB dan pukul $15.00-18.00$ WIB.
Observasi dilakukan secara langsung dengan bantuan alat perekam kamera. Untuk mengetahui durasi waktu setiap perilaku seksual yang dilakukan pejantan ayam Burgo digunakan timer atau stopwatch. Penelitian perilaku ini dilakukan selama bulan April hingga Juni 2018 bertempat di Zona Peternakan Terpadu (Integrated Livestock Zone) Jurusan Peternakan Fakultas Pertanian Universitas Bengkulu. Koleksi data perilaku seksual dilakukan dengan cara mencatat semua perilaku seksual (serial courtship, mounting, mating, dan dismounting) yang terlihat pada saat pengamatan, durasi waktu lamanya serta frekuensi banyaknya perilaku tersebut dilakukan. Rekaman video perilaku seksual yang dilakukan dalam penelitian ini bertujuan agar setiap aktivitas dapat terlihat jelas dan dapat dilihat ulang kembali ketika menganalisis data.

Pejantan ayam Burgo menempati kandang individual berukuran 1,5 x 1,5 x 1,5 $\mathrm{m}^{2}$ beralaskan sekam padi. Adapun untuk memancing jantan menunjukkan perilaku seksual mengawini betina maka dimasukkan 5 ekor ayam Burgo betina dewasa (rasio seks 1:5) ke dalam setiap kandang individual jantan. Adapun parameter perilaku yang diamati dalam penelitian ini adalah berupa serial perilaku seksual mulai dari courtship, mounting, mating dan dismounting yang dapat dilihat pada etogram (Tabel 1).

Tabel 1. Etogram parameter perilaku seksual pejantan ayam Burgo dewasa kelamin

\begin{tabular}{|c|c|c|}
\hline Nomor & Perilaku Seksual & Deskripsi \\
\hline 1 & Courtship $^{\text {a) }}$ & $\begin{array}{l}\text { ayam Burgo jantan melakukan pinangan yaitu diekspresikan } \\
\text { melalui aktivitas tarian waltz, memanjangkan kepala, } \\
\text { menegakkan bulu leher sambil mengejar ayam Burgo betina. }\end{array}$ \\
\hline 2 & Mounting ${ }^{\mathrm{b})}$ & $\begin{array}{l}\text { ayam Burgo jantan mematuk kepala ayam Burgo betina untuk } \\
\text { ditunggangi hingga ayam jantan berhasil menunggangi ayam } \\
\text { betinanya. }\end{array}$ \\
\hline 3 & Mating ${ }^{c)}$ & $\begin{array}{l}\text { ayam Burgo jantan saat menunggangi ayam Burgo betina } \\
\text { kemudian menegakkan jengger dan bulu leher serta mengangkat } \\
\text { dan membuka kloaka dan kemudian ejakulasi. }\end{array}$ \\
\hline 4 & Dismounting ${ }^{\mathrm{d}}$ & $\begin{array}{l}\text { ayam Burgo jantan telah melakukan mating terhadap ayam } \\
\text { Burgo betina dan turun dari badan ayam Burgo betina tersebut. }\end{array}$ \\
\hline
\end{tabular}

40 | Perbandingan frekuensi dan durasi perilaku seksual berdasarkan umur... (Putranto et al., 2019) 
mendekati ayam Burgo betina atau menari mengepakkan sayap dengan mengitari ayam

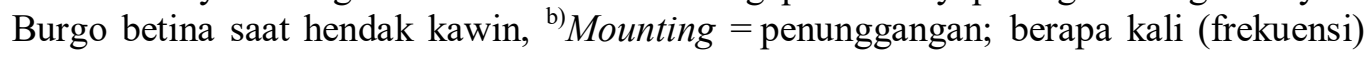
dan berapa lama (durasi) ayam Burgo jantan menunggangi ayam Burgo betina (durasi dalam detik), ${ }^{c}$ Mating = kopulasi; ereksi, intromisi, dan ejakulasi biasanya tidak terlihat, yang terlihat hanya sebatas kloaka ketemu kloaka. Berapa kali (frekuensi) dan berapa lama (durasi) ayam Burgo jantan melakukan kopulasi dalam setiap periode pengamatan (durasi dalam detik), ${ }^{\text {d) }}$ Dismounting = turun dari tubuh betina; berapa kali (frekuensi) dan berapa lama (durasi) ayam Burgo jantan turun dari atas tubuh ayam Burgo betina setelah kopulasi terjadi dalam setiap periode pengamatan (durasi dalam detik).

Data frekuensi dan durasi serial perilaku seksual setiap pejantan ayam Burgo ditabulasi dan dianalisis secara deskriptif. Selanjutnya data ditampilkan dalam bentuk tabel, grafik dan gambar.

\section{HASIL DAN PEMBAHASAN}

Beberapa studi tentang perilaku seksual pada satwa atau hewan seperti pada harimau Siberia (Putranto et al., 2007a), harimau Sumatera (Putranto et al., 2007b), orangutan Sumatera (Putranto et al., 2007c), dan rusa Sambar Sumatera (Putranto et al., 2010) telah dilakukan. Artikel ini menjadi manuskrip ilmiah pertama yang menginformasikan tentang serial perilaku seksual pejantan ayam Burgo. Prijono dan Handini (1996) mendefinisikan perilaku sebagai ekspresi satwa dalam bentuk gerakan-gerakan. Tanudimadja (1978) menjelaskan, perilaku timbul karena adanya rangsangan yang berasal dari dalam tubuh individu atau dari lingkungannya dan perilaku satwa ini berfungsi untuk menyesuaikan diri terhadap perubahan lingkungan baik dari luar maupun dari dalam. Selanjutnya diketahui bahwa perilaku akibat rangsangan terdapat pada hampir semua individu dalam satu spesies, tetapi akan ada perilaku yang tidak didasari oleh pengalaman terlebih dahulu yang disebut dengan perilaku bawaan. Rerata frekuensi dan durasi waktu serial perilaku seksual pejantan ayam Burgo disajikan pada Tabel 2. Data serial perilaku seksual pada Tabel 2 menunjukkan bahwa pejantan ayam Burgo nomor 1 dan 2 yang merupakan ayam Burgo jantan dewasa berumur lebih muda dibandingkan pejantan ayam Burgo nomor 3 dan 4, nampak lebih dominan dalam melakukan perilaku seksual courtship atau perangsangan/perayuan $(14,1$ dan 12,4 kali versus 9,6 dan 9,1 kali).

Tabel 2. Rerata frekuensi dan durasi waktu serial perilaku seksual pejantan ayam Burgo dalam 1 hari selama penelitian

\begin{tabular}{|c|c|c|c|c|c|c|c|c|}
\hline \multirow{2}{*}{$\begin{array}{l}\text { Perilaku } \\
\text { Seksual }\end{array}$} & \multicolumn{2}{|c|}{$\begin{array}{c}\text { Pejantan Ayam } \\
\text { Burgo } 1^{\text {a) }}\end{array}$} & \multicolumn{2}{|c|}{$\begin{array}{l}\text { Pejantan Ayam } \\
\text { Burgo } 2^{\text {b) }}\end{array}$} & \multicolumn{2}{|c|}{$\begin{array}{c}\text { Pejantan Ayam } \\
\text { Burgo } 3^{\mathrm{c})}\end{array}$} & \multicolumn{2}{|c|}{$\begin{array}{c}\text { Pejantan Ayam } \\
\text { Burgo } 4^{\text {d) }}\end{array}$} \\
\hline & $\begin{array}{l}\text { Frek }^{\mathrm{e})} \\
\text { (kali) }\end{array}$ & $\begin{array}{l}\text { Durasi } \\
\text { (detik) }\end{array}$ & $\begin{array}{r}\text { Frek } \\
\text { (kali) }\end{array}$ & $\begin{array}{l}\text { Durasi } \\
\text { (detik) }\end{array}$ & $\begin{array}{r}\text { Frek } \\
\text { (kali) }\end{array}$ & $\begin{array}{l}\text { Durasi } \\
\text { (detik) }\end{array}$ & $\begin{array}{r}\text { Frek } \\
\text { (kali) }\end{array}$ & $\begin{array}{l}\text { Durasi } \\
\text { (detik) }\end{array}$ \\
\hline Courtship $^{\mathrm{f})}$ & 14,1 & 27,98 & 12,4 & 24,93 & 9,6 & 20,02 & 9,1 & 19,00 \\
\hline Mounting ${ }^{\mathrm{g})}$ & 2,8 & 4,88 & 2,2 & 5,51 & 4,7 & 7,73 & 4,4 & 7,65 \\
\hline Mating ${ }^{\mathrm{h}}$ & 2,2 & 3,10 & 1,8 & 2,65 & 4,9 & 6,79 & 4,4 & 6,55 \\
\hline Dismounting ${ }^{\text {i) }}$ & 2,8 & 4,44 & 2,2 & 4,61 & 4,7 & 5,75 & 4,4 & 6,12 \\
\hline
\end{tabular}

Keterangan: ${ }^{\text {a) }}$ Pejantan ayam Burgo dewasa berumur lebih muda (6 bulan), ${ }^{\text {b) }}$ Pejantan ayam Burgo dewasa berumur lebih muda (7 bulan), ${ }^{c}$ Pejantan ayam Burgo dewasa berumur lebih tua (12 bulan), ${ }^{\text {d) }}$ Pejantan ayam Burgo dewasa berumur lebih tua (12 bulan), ${ }^{\mathrm{e})}$ Frek = frekuensi, ${ }^{\mathrm{f}}$ Courtship = perangsangan, ${ }^{\mathrm{g}}$ Mounting = penunggangan, ${ }^{\mathrm{h}}$ Mating = kopulasi, ${ }^{\text {i) }}$ Dismounting $=$ turun dari tubuh betina. 
Perilaku seksual mounting, mating dan dismounting, rerata frekuensinya lebih tinggi pada pejantan ayam Burgo nomor 3 dan 4 yang berumur lebih tua dibandingkan pejantan ayam Burgo nomor 1 dan 2. Hal tersebut diasumsikan karena pengalaman si pejantan untuk mengawini betinanya juga berpengaruh terhadap keberhasilan dalam prosesi kawin atau sampai telah terjadinya ejakulasi ke kloaka betina. Semakin banyak pengalamannya maka akan semakin tinggi tingkat keberhasilan si pejantan untuk mengawini betinanya.

\section{Courtship (Perangsangan)}

Peneliti mendapatkan bahwa tarian waltz merupakan aktivitas utama pada perilaku seksual courtship yang dilakukan pejantan ayam Burgo. Hasil ini sejalan dengan hasil studi yang dilakukan Sujana (2017), dimana proses kawin pada unggas didahului oleh beberapa pola perilaku pinangan yang salah satunya merupakan tarian waltz. Pola perilaku perangsangan atau melakukan tarian waltz pada pejantan ayam Burgo diawali dengan ayam Burgo jantan melihat ayam Burgo betina yang sedang melakukan aktivitas mencari pakan di atas tanah. Selanjutnya ayam Burgo jantan mulai mendekati sambil membungkukkan badannya disertai leher yang dilengkungkan ke arah samping dengan berjalan miring sambil mengibas-ngibaskan sayap. Ayam Burgo jantan perlahan mendekati ayam Burgo betina dan selanjutnya mengitarinya untuk dilakukan prosesi kawin. Menurut Nurandriyanto (2018) dan Sujana (2017), tarian waltz mengekspresikan pejantan ayam Burgo yang melakukan pinangan atau merayu untuk menarik perhatian ayam Burgo betina sebagai salah satu upaya pejantan ayam Burgo untuk membujuk ayam Burgo betina sebelum akhirnya terjadinya perkawinan. Rerata frekuensi perilaku seksual courtship pejantan ayam Burgo selama penelitian dapat dilihat pada Gambar 1.

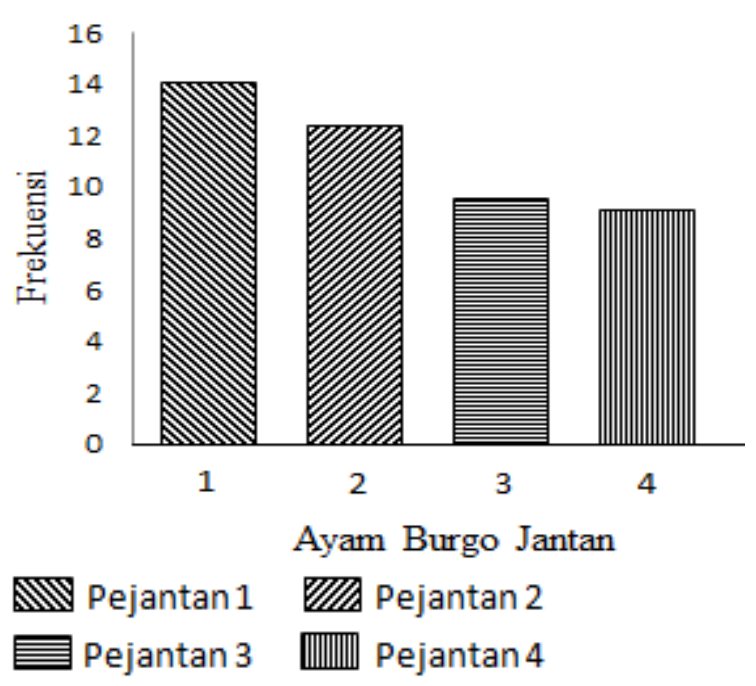

Gambar 1. Grafik rerata frekuensi perilaku seksual courtship pejantan ayam Burgo dalam 1 hari selama penelitian.

Gambar 1 memperlihatkan bahwa rerata frekuensi tertinggi perilaku seksual courtship dalam 1 hari ditunjukkan oleh pejantan ayam Burgo nomor 1 disusul pejantan nomor 2, 3 dan 4. Terdapat beberapa faktor yang mempengaruhi perkawinan pada hewan antara lain aktivitas satwa lain, kesiapan kawin, umur ternak serta jumlah ternak (Ramadhan, 2009). Peneliti berasumsi bahwa pejantan ayam Burgo dewasa berumur lebih muda pada penelitian ini lebih memperlihatkan ambisinya atau keinginannya untuk melakukan kawin. Hal ini terlihat dengan tingginya frekuensi perilaku seksual courtship pada pejantan ayam Burgo nomor 1 dan 2 yang merupakan pejantan dewasa berumur lebih muda. Hasil penelitian ini sejalan dengan pendapat Appleby et al. (2004) yang menyatakan bahwa aktivitas frekuensi kawin pada unggas akan berkurang seiring meningkatnya umur unggas.

Untuk mengetahui rerata durasi waktu perilaku courtship pejantan ayam Burgo dapat dilihat pada Gambar 2. 


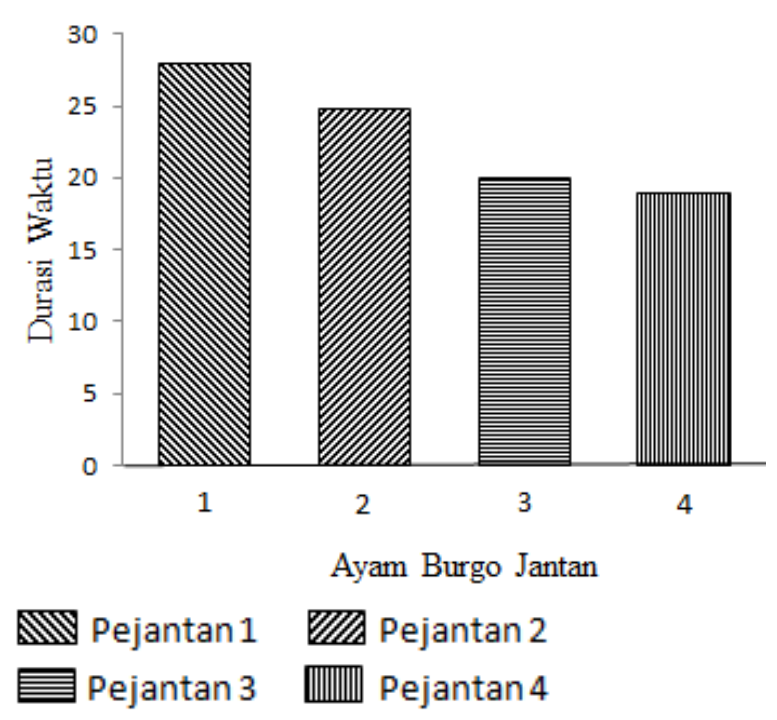

Gambar 2. Grafik rerata durasi waktu perilaku seksual courtship pejantan ayam Burgo selama 1 hari (dalam detik).

Pada Gambar 2 terlihat bahwa rerata durasi waktu perilaku seksual courtship pejantan ayam Burgo dalam 1 hari selama penelitian paling lama terdapat pada jantan nomor 1 disusul oleh jantan nomor 2, 3 dan 4. Pada pejantan ayam Burgo nomor 1 rerata durasi waktu perilaku seksual courtship-nya selama 27,98 detik, kemudian 21,4 detik; 20,02 detik dan 19,00 detik pada pejantan nomor 2, 3 dan 4. Semakin tinggi frekuensi perilaku seksual courtship maka semakin lama durasi waktu untuk melakukan perilaku seksual tersebut. Menurut Prayitno dan Sugiharto (2015), faktor umur unggas dapat mempengaruhi perilaku seksual unggas.

\section{Mounting (Penunggangan)}

Pada penelitian ini, peneliti membatasi perilaku seksual mounting didasarkan atas etogram pada Tabel 1 . Perilaku seksual mounting yang diamati yaitu pejantan ayam Burgo menaiki punggung ayam Burgo betina sebelum terjadinya aktivitas mating. Hasil penelitian memperlihatkan frekuensi dan durasi waktu perilaku seksual mounting yang berbeda pada setiap pejantan (Gambar 3). Rerata frekuensi perilaku seksual mounting tertinggi diperlihatkan oleh pejantan ayam Burgo nomor 3 (4,7 kali) yang merupakan ayam
Burgo jantan dewasa berumur lebih tua. Hasil ini didukung oleh pendapat dari Prayitno dan Sugiharto (2015) yang menyebutkan bahwa faktor umur unggas dapat mempengaruhi perilaku seksual unggas. Peneliti memperkirakan bahwa pejantan ayam Burgo jantan dewasa yang berumur lebih tua memiliki mental yang lebih kuat dibandingkan pejantan ayam Burgo dewasa berumur lebih muda sehingga berani dan bisa melakukan perilaku seksual mounting pada ayam Burgo betinanya.

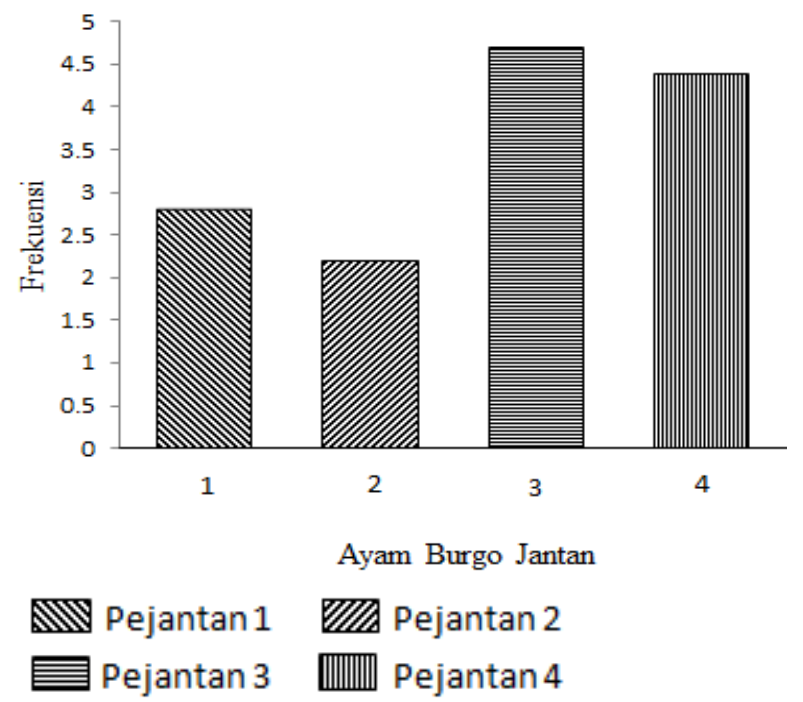

Gambar 3. Grafik rerata frekuensi perilaku seksual mounting pejantan ayam Burgo dalam 1 hari selama penelitian.

Rerata frekuensi tertinggi perilaku seksual mounting pejantan ayam Burgo dalam 1 hari selama penelitian dipelihatkan oleh pejantan ayam Burgo nomor 3 disusul nomor 4, 1 dan 2 (Gambar 3). Diperkirakan faktor internal maupun eksternal berupa hormon seksual dan pakan dapat mempengaruhi frekuensi perilaku seksual. Hal tersebut didasarkan atas pendapat Masyud (2007) yang menyatakan bahwa faktor internal adalah kerja hormon LH dalam proses spermatogenesis. Selanjutnya, dijelaskan bahwa faktor eksternal antara lain adalah faktor asupan pakan dengan kualitas dan keseimbangan gizi yang cukup.

Selanjutnya, rerata durasi waktu perilaku seksual mounting pejantan ayam 
Burgo jantan dapat dilihat pada Gambar 4 berikut.
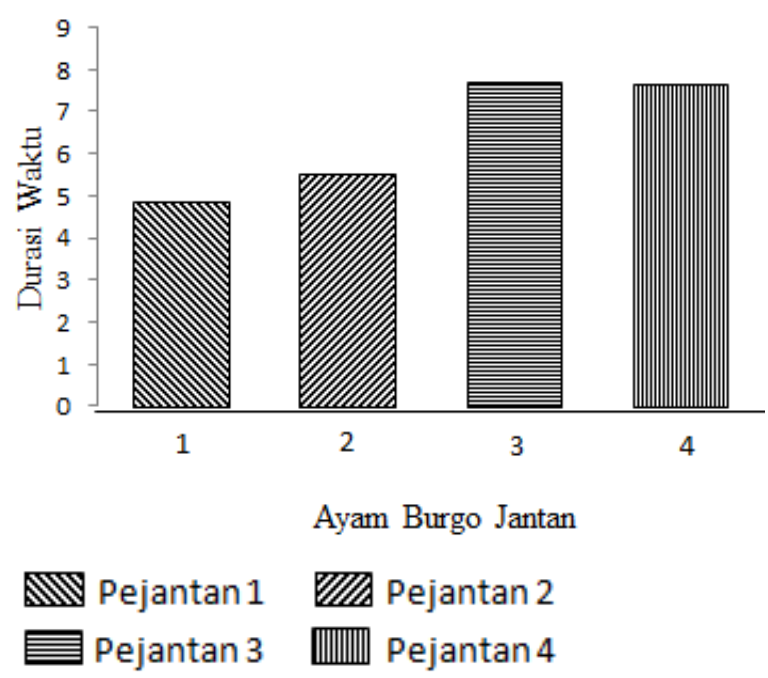

Gambar 4. Grafik rerata durasi waktu perilaku seksual mounting pejantan ayam Burgo dalam 1 hari selama penelitian (dalam detik)

Grafik batang pada Gambar 4 memperlihatkan bahwa rerata durasi waktu tertinggi perilaku seksual mounting pejantan ayam Burgo ditunjukkan oleh ayam jantan nomor 3 disusul nomor 4, 2 dan 1. Rerata durasi waktu tertinggi adalah 7,73 detik dan terendah selama 4,88 detik. Hasil penelitian memperlihatkan kecenderungan pejantan ayam Burgo dewasa yang berumur lebih muda lebih sedikit melakukan perilaku seksual mounting dibandingkan pejantan dewasa berumur lebih tua sehingga durasi waktu yang dicurahkan untuk melakukan perilaku seksual mounting juga lebih pendek (Gambar 3 dan 4).

Perbedaan frekuensi dan durasi waktu perilaku seksual mounting pada pejantan ayam Burgo diasumsikan juga sebagai akibat dari umur pejantan yang lebih muda (jantan nomor 1 dan 2) sehingga kurang berpengalaman. Selanjutnya Masyud (2007) menyebutkan bahwa betina yang belum siap secara fisiologis biasanya akan menghindar atau menjauh jika didekati atau dicumbu jantan. Betina yang terlihat cocok dan siap kawin akan tampak diam jika pejantan mulai mendekati, mencumbui dan belajar menungganginya, serta memberikan respon siap dikawini.

\section{Mating (Kopulasi)}

Menurut etogram pada Tabel 1, perilaku seksual mating diasumsikan terjadi saat pejantan ayam Burgo menaiki dan telah berada di atas punggung ayam Burgo betina untuk melakukan kopulasi yang diakhiri dengan ejakulasi yang diperlihatkan melalui bertemunya kloaka jantan dengan kloaka betina. Gambar 5 memperlihatkan bahwa rerata frekuensi dan durasi waktu perilaku seksual mating yang berbeda pada setiap pejantan. Pola rerata frekuensi perilaku seksual mating pada pejantan ayam Burgo terlihat sama dengan pola rerata frekuensi perilaku seksual mounting (Gambar 3). Rerata frekuensi tertinggi diperlihatkan oleh pejantan nomor 3 (4,9 kali) disusul oleh pejantan nomor 4, 1 dan $2(4,4 ; 2,2$ dan 1,8 kali, Gambar 5).

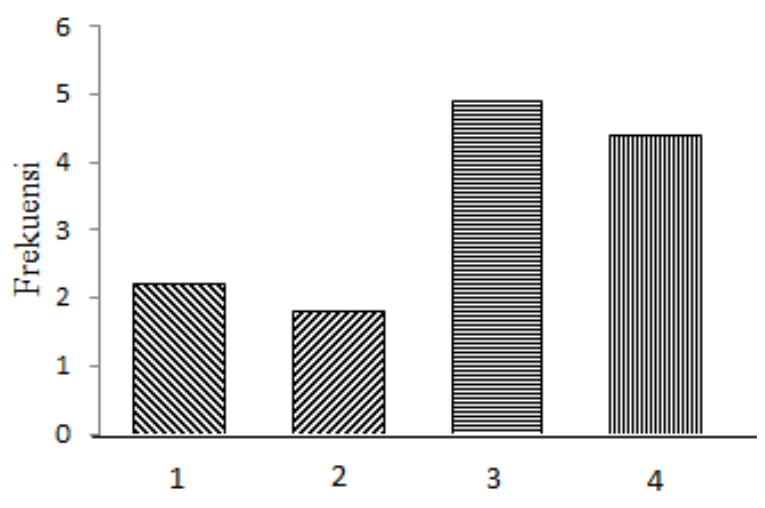

Ayam Burgo Jantan

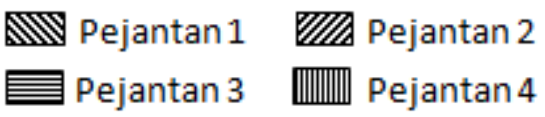

Gambar 5. Grafik rata-rata frekuensi tingkah laku seksual mating pejantan ayam Burgo dalam 1 hari selama penelitian

Hasil penelitian ini sekaligus membuktikan bahwa pejantan ayam Burgo dewasa berumur lebih tua lebih tinggi frekuensinya dalam melakukan serial perilaku seksual. Hal tersebut berdampak pada keberhasilan ejakulasi atau deposisi semen pada kloaka betina. Hal ini juga sejalan dengan Ramadhan (2009) yang 
menambahkan bahwa faktor yang mempengaruhi perkawinan yaitu aktivitas satwa lain, kesiapan kawin, umur ternak serta jumlah ternak. Lebih jauh, rerata durasi waktu perilaku seksual mating pejantan ayam Burgo dapat dilihat pada Gambar 6.

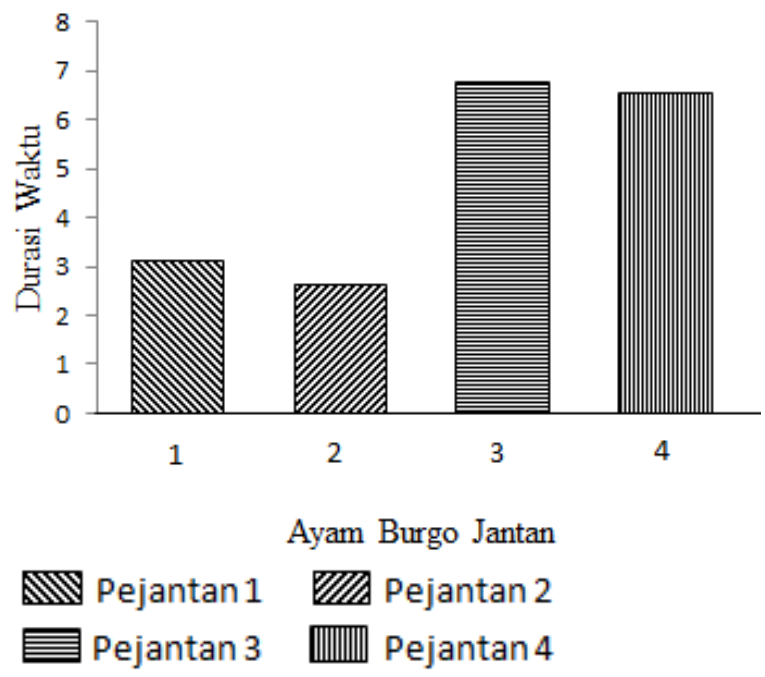

Gambar 6. Grafik rerata durasi waktu perilaku seksual mating pejantan ayam Burgo dalam 1 hari selama penelitian (dalam detik)

Rerata durasi waktu tertinggi perilaku seksual mating pejantan ayam Burgo dilakukan oleh jantan nomor 3 (6,79 detik) disusul oleh jantan nomor 4, 1 dan 2 (6,55; 3,1 dan 2,65 detik; Gambar 6). Berdasarkan data tersebut maka dapat diketahui bahwa pejantan ayam Burgo yang berumur lebih tua lebih dominan berhasil melakukan aktivitas perilaku seksual mating dibandingkan pejantan berumur lebih muda. Faktor umur dapat mempengaruhi perilaku seksual unggas (Prayitno dan Sugiharto, 2015). Selain disebabkan oleh pengalaman yang lebih banyak dimiliki oleh pejantan berumur lebih tua, pengaruh hormon dan pakan juga diasumsikan memegang peranan. Perilaku seksual akan dipengaruhi oleh konsentrasi hormon reproduksi seperti hormon LH (Masyud, 2007).

\section{Dismounting (Turun dari Atas Tubuh Betina)}

Serial perilaku seksual terakhir yang diamati pada penelitian ini adalah dismounting. Setiap pejantan ayam Burgo yang melakukan perilaku seksual mounting pasti akan melakukan perilaku seksual dismounting. Rerata frekuensi perilaku seksual dismounting pejantan ayam Burgo jantan dapat dilihat pada Gambar 7.

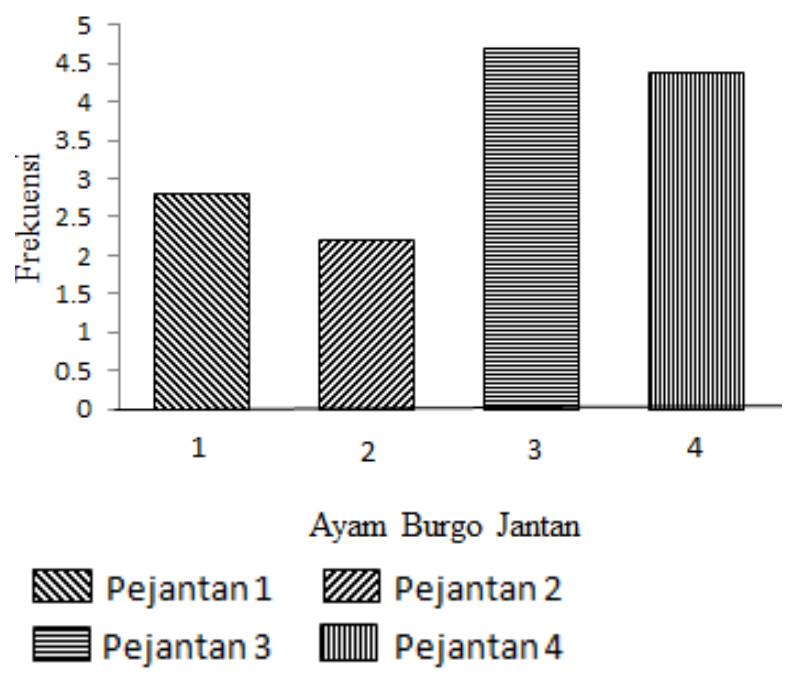

Gambar 7. Grafik rerata frekuensi perilaku seksual dismounting pejantan ayam Burgo dalam 1 hari selama penelitian

Pada Gambar 7 dapat dilihat bahwa rerata frekuensi tertinggi perilaku seksual dismounting pejantan ayam Burgo terdapat pada jantan nomor 3 kemudian disusul oleh jantan nomor 4, 1 dan 2. Frekuensi yang lebih rendah ditunjukkan oleh pejantan ayam Burgo dewasa yang berumur lebih muda $(2,8$ dan 2,2 kali). Sedangkan pejantan ayam Burgo yang berumur lebih tua memiliki frekuensi perilaku seksual dismounting yang lebih tinggi (4,7 dan 4,4 kali). Pada observasi yang telah dilakukan, didapati hasil rerata frekuensi dan durasi waktu perilaku seksual dismounting pada pejantan ayam Burgo yang berbeda antar individu dimana terdapat pula pola kemiripan yang sama dengan pola serial perilaku seksual sebelumnya. Selanjutnya, rerata durasi waktu perilaku seksual dismounting pejantan ayam Burgo dapat dilihat pada Gambar 8 . 


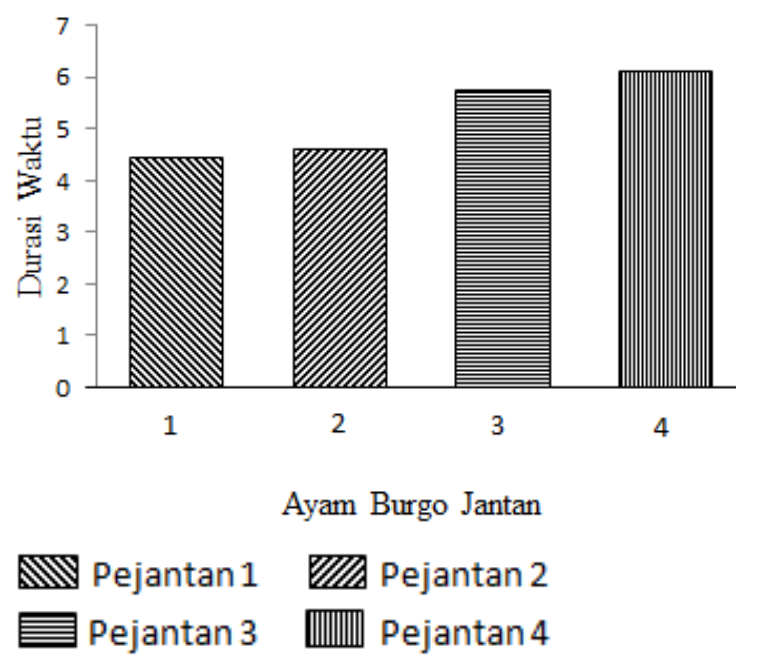

Gambar 8. Grafik rerata durasi waktu perilaku seksual dismounting pejantan ayam Burgo dalam 1 hari selama penelitian

Gambar 8 memperlihatkan bahwa rerata frekuensi perilaku seksual dismounting pejantan ayam Burgo dalam 1 hari selama penelitian menunjukkan rerata durasi waktu tertinggi terdapat pada jantan nomor $4(6,12$ detik) disusul oleh jantan nomor $3(5,75$ detik), 2 (4,61 detik) dan 1 (4,44 detik). Perilaku seksual dismounting ini berhubungan erat dengan serial perilaku seksual sebelumnya yaitu mounting. Pejantan ayam Burgo nomor 3 dan 4 lebih dominan melakukan perilaku seksual mounting sehingga juga otomatis dominan dengan perilaku seksual dismounting. Secara alami, hal ini terjadi karena pejantan ayam Burgo yang naik ke atas punggung ayam Burgo betina pasti akan turun kembali baik itu post ejakulasi atau belum ejakulasi.

\section{KESIMPULAN}

Berdasarkan hasil penelitian diketahui bahwa pejantan ayam Burgo dewasa yang berumur lebih tua lebih tinggi frekuensi perilaku seksualnya, kecuali pada perilaku seksual courtship dimana pejantan ayam Burgo yang berumur lebih muda lebih aktif.

\section{UCAPAN TERIMAKASIH}

Tim peneliti mengucapkan terima kasih kepada Direktorat Jenderal Penguatan Riset dan Pengembangan (DRPM) Kementerian Riset, Teknologi dan Pendidikan Tinggi Republik Indonesia yang telah membiayai seluruh penelitian ini melalui Hibah Penelitian Berbasis Kompetensi (PBK) dengan nomor kontrak: 534/UN30.15/LT/2018 tanggal 13 Februari 2018. Ucapan terima kasih juga diucapkan kepada Jurusan Peternakan Fakutas Pertanian Universitas Bengkulu, dan LPPM Universitas Bengkulu. Kepada mahasiswa anggota tim penelitian Edi Nurandriyanto, Devi Putra dan Rizki Putri Ramadhani serta saudara Arif Nufarm yang telah banyak membantu jalannya penelitian, diucapkan penghargaan dan ucapan terima kasih.

\section{DAFTAR PUSTAKA}

Anonim. 2019. https://bengkuluprov.go.id/tag/visitbengkulu-2020/. diakses tanggal 1 Maret 2019.

Anonim. 2017. http//tingkahlakubehavior//wordpress.c om. diakses pada tanggal 1 Maret 2019.

Appleby, M.C., J.A. Mench, dan B.O. Hughes. 2004. Poultry Behaviour and Welfare. Center of Agriculture Bioscientific (CAB) Publishing. London.

Handika, D. 2018. Studi Morfometrik Ayam Burgo Betina di Provinsi Bengkulu. Jurusan Peternakan Fakultas Pertanian Universitas Bengkulu, Bengkulu. Skripsi.

Masyud, B. 2007. Pola reproduksi burung tekukur (Streptopelia chinensis) dan telur (Streptopelia risoria) di penangkaran. Media Konservasi, 12 (2) : 80-88.

Nareswari, N. D., D. Samsudewa, dan Y. S. Ondho. 2017. Tingkah laku reproduksi merak hijau (Pavo muticus) pada umur 
yang berbeda di UD. Tawang Arum Kecamatan Gemarang, Kabupaten Madiun. Jurnal Sain Peternakan Indonesia. 12 (1) : 94-101.

Nurandriyanto, E. 2018. Variasi Tingkah Laku Reproduksi Ayam Burgo Jantan Pada Pemeliharaan Intensif. Jurusan Peternakan Fakultas Pertanian Universitas Bengkulu, Bengkulu. Skripsi.

Prayitno, D. S., dan Sugiharto. 2015. Kesejahteraan dan Metode Penelitian Tingkah Laku Unggas. Badan Penerbit Universitas Diponegoro, Semarang.

Prijono, N.S., dan S. Handini. 1996. Memelihara, Menangkar, dan Melatih Nuri. Penebar Swadaya. Jakarta.

Putranto, H.D. 2011. Introduction of indigenous Bengkulu chicken, population, female production and reproductive organs describtion. Proc. of the 19th J-AREA Annual Meeting, Himeji City, Japan, p : 9.

Putranto H. D., J. Setianto, Y. Yumiati., dan D. Handika. 2018. Analyses of body and chest morphometric comparison between two Indonesian local poultry species. International Journal of Agricultural Technology, 14 (7) : 17191730.

Putranto, H.D., G.P. Hasibuan, Y. Yumiati, J. Setianto, B. Brata, N. Kurniati, dan F.F. Hakiki. 2017. The estimation of dynamical distribution of domesticated burgo chicken population in Bengkulu coastal area Indonesia. Biodiversitas, 18 (2): 458-464.

Putranto, H.D., J. Setianto, N. Kurniati, Y. Yumiati, dan G.P. Hasibuan. 2016. Characteristic overview on burgo in Bengkulu costal area. International Seminar Untilization of Natural Resources In Tropical Zone. Bengkulu, Indonesia.
Putranto, H. D., U. Santoso, Warnoto, Nurmeliasari, J. Setianto, B. Brata, A. Susilo, Y. Yumiati, S. Matsumura, dan O. Doi. 2012a. Bengkulu endemic burgo chicken genetic assessed by mtDNA D-loop region. Proc. The $1^{\text {st }}$ Poultry International Seminar 2012 : $249-253$.

Putranto, H. D, J. Setianto, dan U. Santoso. 2012b. Estradiol- $7 \beta$ hormone concentration and follicles number in exotic burgo chicken supplemented by Sauropus androgynus leaves extract. Biodiversitas, 13 (1) : 1-6.

Putranto, H. D., U. Santoso, dan Warnoto. 2010a. A study on population density and distribution pattern of domesticated Bengkulu native burgo chicken. Media Kedokteran Hewan, 26 (2) : 198-204.

Putranto, H. D., E. Soetrisno, Nurmeliasari, A. zueni, dan B. Gibson. 2010b. Recognition of seasonal effect on captive Sumateran sambar deer reproductive cyclicity and sexual behaviors. Biodiversitas, 11 (4) : $200-$ 203.

Putranto, H. D, S. Kusuda, K. Inagaki, G. Kumagai, R. Ishii-Tamura, Y. Uziie, dan O. Doi. 2007a. Ovarian activity and pregnancy in the Siberian tiger, Panthera tigris altaica, assessed by fecal gonadal steroid hormones analyses. Journal of Veterinary Medicine Science, 69 (5) : 569 - 571.

Putranto, H. D, S. Kusuda, H. Hashikawa, K. Kimura, H. Naito, dan O. Doi. 2007b. Fecal progestins and estrogens for endocrine monitoring of ovarian cycle and pregnancy in Sumatran orangutan (Pongo abelii). Japanese Journal of Zoo and Wildlife Medicine, 12 (2) : 97 -103 .

Putranto, H. D., S. Kusuda, T. Ito, M. Terada, K. Inagaki, dan O. Doi. 2007c. Reproductive cyclicity based on fecal 
steroid hormones and behaviors in Sumatran tigers, Panthera tigris sumatrae. Japanese Journal of Zoo and Wildlife Medicine, 12 (2) : 111 - 115.

Ramadhan, G. F. 2009. Ekologi perilaku berbiak merak hijau (Pavo muticus linnaeus, 1766) di Taman Nasional Alas Purwo dan Baluran Provinsi Jawa Timur. Departemen Konservasi Sumberdaya Hutan dan Ekowisata. Fakultas Kehutanan Institut Pertanian Bogor, Bogor. Skripsi.

Sawitri, R., dan M. Takandjandji. 2010. Management and behaviour of eagles at Wildlife Rescue Center of Cikananga Sukabumi. Jurnal Penelitian Hutan dan Konservasi Alam, VII (3) : $257-270$.

Setianto, J., Sutriyono, H. Prakoso, B. Zain, R. Adwiyansyah, dan A. H. K. Amrullah. 2019. Phenotypic diversity of male Burgo chicken from Bengkulu, Indonesia. Biodiversitas, 20 (2) : 532536 .
Setioko, A.R. 2001. Inseminasi buatan pada itik. Disampaikan pada Acara Pelatihan Inseminasi Buatan pada Itik di BPT HMT Pelaihari Kalimantan Selatan. Tambang Ulang, 30-31 Agustus 2001.

Sujana, E. 2017. Sumber Belajar Penunjang PLPG Mata Pelajaran/Paket Keahlian, Agribisnis Ternak Unggas, Tingkah Laku Ternak Unggas. Kementerian Pendidikan Dan Kebudayaan Direktorat Jenderal Guru dan Tenaga Kependidikan. Jakarta.

Tanari, M. 2007. Karakterisasi habitat, morfologi dan genetik serta pengembangan teknologi penetasan exsitu burung Maleo (Macrocephalon maleo Sal. Muller 1846) sebagai upaya meningkatkan efektivitas konservasi. Sekolah Pascasarjana, Institut Pertanian Bogor. Bogor.

Tanudimadja. $\quad$ 1978. School of Environmental Conservation Management. Ciawi, Bogor. 